\title{
Textural and sensory characteristics of oven baked and steamed bread
}

\author{
Dele Raheem ${ }^{1,2 *}$, Aiping Liư ${ }^{2}$, Cheng $\mathrm{Li}^{2}$ \\ ${ }^{1}$ Arctic Centre (NIEM), University of Lapland, 96101 Rovaniemi, Finland, ${ }^{2}$ College of Food Science, Sichuan Agricultural University, \\ 625014 Ya'an, China
}

\section{A B S TR A C T}

The consumption of bread as a staple food is global and it is one of the oldest food for humans. However, the processing methods and the acceptability of bread products differs from region to region based on culture. In this study, we aim to understand how different processing methods can influence the texture and sensory characteristics of the final bread products. Resilience and firmness of oven baked and steamed bread were determined by Texture Profile Analysis (TPA). The results shows higher resilience and lower firmness in steamed bread. In addition, we investigated the supplementation of banana milk juice on bread. The results showed that more banana milk juice in bread could lead to lower resilience but more firmness in both oven and steamed bread. The effect of storage temperature at room temperature, $+4{ }^{\circ} \mathrm{C}$ and $-20{ }^{\circ} \mathrm{C}$ over time on the resilience and firmness of both bread were also investigated. Both firmness and resilience increased over time in both oven baked and steamed bread.

Keywords: Oven baked, Sensory, Steamed bread, Texture

\section{INTRODUCTION}

Bread is the oldest and most varied type of food in baked goods and it is a staple food in many countries of the world. In most cases, bread is made from wheat flour, yeast, salt and water as basic raw materials, appropriate amount of sugar, grease, dairy products, eggs and additives and other auxiliary materials may be added through stirring, fermentation, shaping, molding, proofing, baking, cooling and other processes to produce bulky, soft, flexible foods (Xiao, 2018). Bread baking is a complex process involving many physical and chemical changes. The optimum baking process depends on the type of bread to be baked and the desired bread characteristics. The ingredients that make up the dough and their processing conditions have a vital effect on the development of the crumb structure in bread and other leavened products (Rathnayake et al., 2018). The authors further suggested that the modifications of factors such as the addition of certain additives like hydrocolloids/ gums, enzymes, and emulsifiers can impact the properties of porous crumb structure and crumb staling.

Consumers' habits and preference on the choice of bread are influenced by culture and tradition. For instance, flat breads are the oldest of all bread products and are widely consumed in North Africa, Southern Europe, the MiddleEast, Indian subcontinent, Turkey and Central America (Qarooni et al., 1992). Oven baked bread is popular in the Western world while in China and other Asian countries, bread are generally steamed. Chinese steamed bread (CSB) is the most popular traditional fermented wheat food in China, representing approximately $40 \%$ of total wheat consumption in China (He et al., 2003). CSB is also widely consumed in other Asian countries (such as Japan, South Korea, Philippines, and Thailand).

Chinese steamed bread (CSB) is commonly called 'mantou'. The dough for steamed bread is made from fermented wheat flour and the resulting product is cooked in a steamer above boiling water to produce a roll-sized product with a smooth, white skin and no crust (BIRT, 2010).

There are two major types of steamed bread: Northern Style, which is preferred in Northern China has a chewy and dense texture; while the Southern Style, which is common in Southern China is more open with a softer texture (Huang and Miskelly, 1991). The northern style steamed bread has a very cohesive, elastic and dense texture

\footnotetext{
*Corresponding author:

Dele Raheem, Arctic Centre (NIEM), University of Lapland, 96101 Rovaniemi, Finland, College of Food Science, Sichuan Agricultural

University, 625014 Ya $\square$ an, China. E-mail: braheem@ulapland.fi
}

Received: 21 June 2019; Accepted: 18 August 2019 
while the southern-style steamed bread have a more open crumb structure, softer texture and a white surface. In the production process, steamed and oven-baked bread are very different in their procedures. The method of production accounts for differences in the structure, flavor, nutritional value and shelf life under storage of steamed and oven baked bread.

In the present study, the objective is to compare how processing conditions in oven baked and steamed bread affect their textural and sensory characteristics. In addition, we investigated the effect of storage temperature and the effect of banana juice supplementation in both types of bread.

\section{MATERIALS AND METHODS}

\section{Materials and chemicals}

Haiwang High-gluten bread flours with $13.68 \%$ moisture content and $11.6 \%$ protein content were purchased from a local supermarket (Yaan, China). Dry yeast, salt and banana milk juice (Weikezi, Yili milk Co., Ltd.), were also bought from local supermarkets.

A sourdough feed was used to prepare the starter (Galle et al., 2012). For the natural sourdough starter preparation: Wheat flour and autoclaved tap water were mixed to obtain a dough yield of $150 \mathrm{~g}$. Dough yield $=[(\mathrm{g}$ flour $+\mathrm{g}$ water $) / \mathrm{g}$ flour $\times 100$ ). The sourdough starter was fermented at $37^{\circ} \mathrm{C}$ for $18 \mathrm{~h}$ overnight in the bread ferment cabinet as shown in Fig. 1 below.

\section{Preparation of oven baked and steamed bread}

The oven baked and steamed bread were prepared with the following ingredients: $500 \mathrm{~g}$ of wheat flour, $400 \mathrm{ml}$ of water, $16 \mathrm{~g}$ of yeast and $1 / 4$ teaspoon salt. For the steamed bread, we also add $150 \mathrm{~g}$ starter dough and $3 \mathrm{~g}$ sodium carbonate. No-time fermentation was used, the flour, water, starter dough and sodium carbonate were mixed (the alkali ensures a no-time fermentation as it neutralises the acid). The resulting dough was moulded, proofed and baked or steamed. The effect of banana milk juice at the following supplementation levels $(0,10 \%, 20 \%, 30 \%, 40 \%$ and $50 \%$ ) on the flavor of bread was also investigated. The banana milk juice replaced water at the supplementation stage (e.g. at $10 \%$ level, $40 \mathrm{ml}$ of banana milk juice was added to $360 \mathrm{ml}$ of water).

The dough was allowed to proof at $25^{\circ} \mathrm{C}$ for $30 \mathrm{~min}$. The dough were baked at $225^{\circ} \mathrm{C}$ for $30 \mathrm{~min}$ or $110{ }^{\circ} \mathrm{C}$ for $20 \mathrm{~min}$ to make the oven baked and steamed bread respectively as shown in Fig. 2 below.

Furthermore, the effect of storage temperature on the resilience and firmness of bread were investigated. Briefly, samples of both oven baked and steamed bread were divided into 2 groups, they were stored at room temperature $\left(+20^{\circ} \mathrm{C}\right)$, refrigeration temperature $\left(+4{ }^{\circ} \mathrm{C}\right)$ and freezing temperature $\left(-20^{\circ} \mathrm{C}\right)$.

\section{Texture profile analysis (TPA) of oven baked and steamed bread}

Determination of textural properties of bread was according to the method described by the manufacturer of TA-XT Plus Texture Analyzer (Stable Micro System Ltd. Haslemere, Surrey, UK). The analyzer is equipped with a $\mathrm{P} / 36 \mathrm{R}$ (36 $\mathrm{mm}$ cylinder probe) to analyze the resilience and firmness of different sliced load bread formulations by penetration. The procedure followed were: Compression procedure, with a compression speed of $10 \mathrm{~mm} / \mathrm{s}$, compress to $\%$ of original height: $25 \%$, compression hold time: 2 s, recovery time: $15 \mathrm{~s}$.

\section{Sensory evaluation of oven baked and steamed bread} To evaluate the sensory properties of bread, a sensory scoring criteria was developed, we evaluate the sensory scores from five aspects including shape, surface color, internal color, inside organization structure and distribution

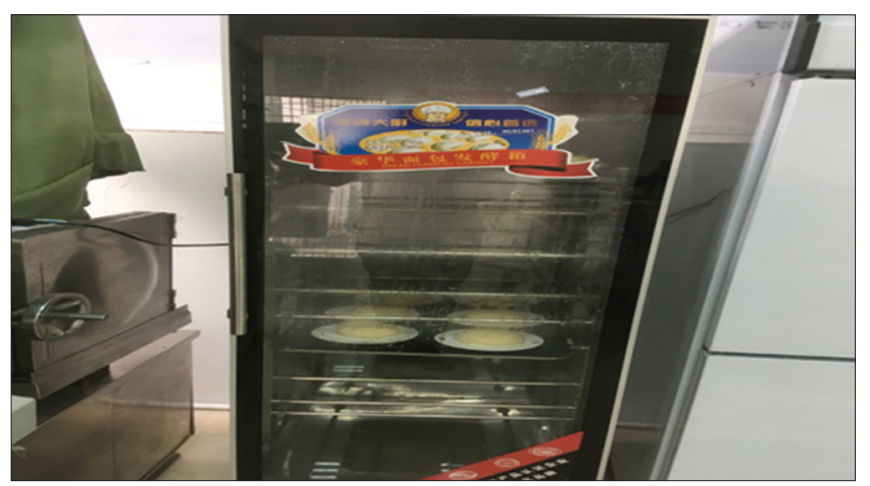

Fig 1. Samples of starter dough fermentation in the bread ferment cabinet

Mix wheat flour, yeast, water, and salt (starter + soda carbonate)<smiles>C1CCCCC1</smiles>

Proof at $25^{\circ} \mathrm{C}$ for $30 \mathrm{~min}$<smiles>C1CCCCC1</smiles>

Knead for $5 \mathrm{~min}$

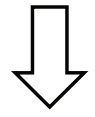

Oven bake at $225^{\circ} \mathrm{C}$ for $30 \mathrm{~min}$ or steam for $20 \mathrm{~min}$

Fig 2. Production process for oven baked and steamed bread 
uniformity of internal structure, detail information were presented in Table 1. Results from sensory evaluation are shown in Table 2.

The sensory evaluation team comprises of Masters students at the College of Food Science of Sichuan Agricultural University, Ya'an, China. There were 70 panelists from the three units of the College - Food Processing and Safety; Food Science and Technology; and Food Engineering.

\section{RESULTS AND DISCUSSION}

The final products from the oven baked and steamed bread were quite visibly different as shown in the representative samples in Fig. 3. In the samples below, the color of the baked bread is golden yellow, the crust is hard while the crumb is soft. For the steamed 'man-tou' bread, there is no crust, there is white color both inside and out. However, the external appearance is smooth with a semi glossy finish.

\section{Effect of storage temperature and time on the texture of oven baked and steamed bread}

The effect of storage temperature under different conditions over time on the textural characteristics (resilience and firmness) were evaluated. The results as shown in Table 3 were obtained from the texture analyzer.

At room temperature, the average resilience on the first day for oven baked bread increased from $20.22 \mathrm{~g}$ to $100 \mathrm{~g}$

Table 1. Effect of storage time on the textural characteristics of banana supplemented oven-baked and steamed bread*

\begin{tabular}{|c|c|c|c|c|c|c|}
\hline & \multicolumn{3}{|c|}{$\begin{array}{c}\text { Oven baked bread } \\
\text { Storage time at room temperature }\end{array}$} & \multicolumn{3}{|c|}{$\begin{array}{c}\text { Steamed bread } \\
\text { Storage time at room temperature }\end{array}$} \\
\hline & $\mathrm{Oh}$ & $72 \mathrm{~h}$ & $105 \mathrm{~h}$ & $\mathrm{Oh}$ & $72 \mathrm{~h}$ & $105 \mathrm{~h}$ \\
\hline \multicolumn{7}{|l|}{ Control } \\
\hline Resilience & 20.22 & 100.00 & 99.02 & 51.53 & 60.37 & 65.14 \\
\hline Firmness & 452.52 & 3933.07 & 12824.42 & 412.00 & 2569.08 & 6502.68 \\
\hline \multicolumn{7}{|l|}{$10 \%$} \\
\hline Resilience & 20.02 & 98.80 & 97.48 & 51.27 & 60.08 & 64.75 \\
\hline Firmness & 455.26 & 3933.97 & 12825.12 & 413.46 & 2578.46 & 6588.34 \\
\hline \multicolumn{7}{|l|}{$20 \%$} \\
\hline Resilience & 19.62 & 86.52 & 96.28 & 50.94 & 59.76 & 64.08 \\
\hline Firmness & 457.18 & 3934.22 & 12826.04 & 414.10 & 2579.28 & 6610.28 \\
\hline \multicolumn{7}{|l|}{$30 \%$} \\
\hline Resilience & 19.42 & 84.20 & 94.48 & 50.02 & 58.92 & 63.21 \\
\hline Firmness & 461.24 & 3934.96 & 12827.00 & 414.94 & 2582.34 & 6706.56 \\
\hline \multicolumn{7}{|l|}{$40 \%$} \\
\hline Resilience & 19.05 & 81.18 & 94.02 & 49.38 & 57.88 & 62.24 \\
\hline Firmness & 463.52 & 3935.44 & 12828.56 & 415.87 & 2584.26 & 6818.24 \\
\hline \multicolumn{7}{|l|}{$50 \%$} \\
\hline Resilience & 18.58 & 80.78 & 90.08 & 48.62 & 56.58 & 61.53 \\
\hline Firmness & 465.28 & 3936.72 & 12829.22 & 416.92 & 2621.14 & 6911.02 \\
\hline
\end{tabular}

*average of 60 samples

Table 2. Sensory scoring criteria of steam bread and baked bread

\begin{tabular}{|c|c|c|c|c|c|}
\hline & Excellent $^{\mathrm{b}}$ & Well & qualified & poor & much poor \\
\hline Shape & $\begin{array}{l}\text { Full shape, complete, no } \\
\text { damage,smooth surface } \\
\text { and suitable size }\end{array}$ & $\begin{array}{l}\text { Complete shape, but } \\
\text { slightly deformed and the } \\
\text { surface is slightly rough }\end{array}$ & $\begin{array}{l}\text { Complete shape, } \\
\text { but the surface is } \\
\text { damaged }\end{array}$ & Incomplete shape & $\begin{array}{l}\text { Incomplete shape, } \\
\text { uneven and the surface is } \\
\text { damaged }\end{array}$ \\
\hline Surface color & Uniform surface color & $\begin{array}{l}\text { The surface is dark } \\
\text { and dull, and the color } \\
\text { distribution is slightly } \\
\text { uneven }\end{array}$ & $\begin{array}{l}\text { Uneven surface } \\
\text { color distribution }\end{array}$ & $\begin{array}{l}\text { Uneven surface } \\
\text { color, white } \\
\text { edges }\end{array}$ & $\begin{array}{l}\text { Uneven surface color, there } \\
\text { is a clear zoom or yellowing } \\
\text { phenomenon }\end{array}$ \\
\hline Internal color & $\begin{array}{l}\text { The color is white and } \\
\text { glossy }\end{array}$ & $\begin{array}{l}\text { Color white, and a little } \\
\text { dim }\end{array}$ & $\begin{array}{l}\text { Uneven color } \\
\text { distribution }\end{array}$ & $\begin{array}{l}\text { The color is } \\
\text { slightly yellowish }\end{array}$ & $\begin{array}{l}\text { Uneven color, faint } \\
\text { yellowish }\end{array}$ \\
\hline Internal structure & $\begin{array}{l}\text { Soft skin, moderate } \\
\text { elasticity, clear lines, } \\
\text { even cut surface pore } \\
\text { size }\end{array}$ & $\begin{array}{l}\text { Better elasticity, no lines, } \\
\text { hard texture and no } \\
\text { fracture after slicing }\end{array}$ & $\begin{array}{l}\text { The surface is } \\
\text { hard and there } \\
\text { is obvious crack, } \\
\text { elasticity is general }\end{array}$ & $\begin{array}{l}\text { Hard surface, no } \\
\text { obvious elasticity, } \\
\text { uneven size of } \\
\text { cut surface pores }\end{array}$ & $\begin{array}{l}\text { The surface is hard or } \\
\text { collapsed, inelastic, and } \\
\text { the face size is extremely } \\
\text { uneven }\end{array}$ \\
\hline $\begin{array}{l}\text { uniformity of } \\
\text { internal structure }\end{array}$ & $\begin{array}{l}\text { No particles, uniform } \\
\text { and delicate pores }\end{array}$ & $\begin{array}{l}\text { Pores distribution is more } \\
\text { uniform, but not delicate } \\
\text { enough }\end{array}$ & $\begin{array}{l}\text { Small pores, loose } \\
\text { structure }\end{array}$ & $\begin{array}{l}\text { Large and loose } \\
\text { or small and solid } \\
\text { pores }\end{array}$ & $\begin{array}{l}\text { large or small pores, } \\
\text { unevenly distributed }\end{array}$ \\
\hline
\end{tabular}

a70 students were involved in this experiment. ${ }^{\mathrm{b}}$ The scores for the five sensory evaluation levels - excellent, good, acceptable, poor, and very poor are 8-10 points, 6-8 points, 4-6 points, 2-4 points, and 0-2 points respectively. 
after three days (72 h) and there was a slight decrease after four days $(105 \mathrm{~h})$. For the steamed bread, there was an increase after three days $(72 \mathrm{~h})$ and further increase after four days (105 h) at $65.14 \mathrm{~g}$. The average firmness similarly increased for oven baked bread samples from $452.52 \mathrm{~g}$ to $3933.07 \mathrm{~g}$ after three days with subsequent increase to $12,824.42 \mathrm{~g}$ after four days while for steamed bread the increase was from $412 \mathrm{~g}$ on the first day and after four days it has increased to $6502.08 \mathrm{~g}$.

At refrigeration temperature, for the oven baked bread, the average resilience on the third day $(72 \mathrm{~h}$ ) slightly increased to $22.22 \mathrm{~g}$ and a further increase to $75.91 \mathrm{~g}$ was observed after four days $(105 \mathrm{~h})$. On the other hand, for the steamed bread there was an increase to $61.15 \mathrm{~g}$ after three days followed by a decrease to $52.29 \mathrm{~g}$ after four days (105 h). The average firmness increased for oven baked bread samples to $3000 \mathrm{~g}$ after three days with subsequent increase to $4794.15 \mathrm{~g}$ after four days while for steamed bread the increase was $1364.72 \mathrm{~g}$ after three days and after four days it has increased to $5928.20 \mathrm{~g}$.

At freezing temperature, the average resilience on the third day $(72 \mathrm{~h}$ ) increased to $61.37 \mathrm{~g}$ and a further slight increase to $63.88 \mathrm{~g}$ was observed after four days (105 h). On the other hand, for the steamed bread there was an increase from $19.47 \mathrm{~g}$ after three days to $55.43 \mathrm{~g}$ after four days $(105 \mathrm{~h})$. The average firmness increased for oven

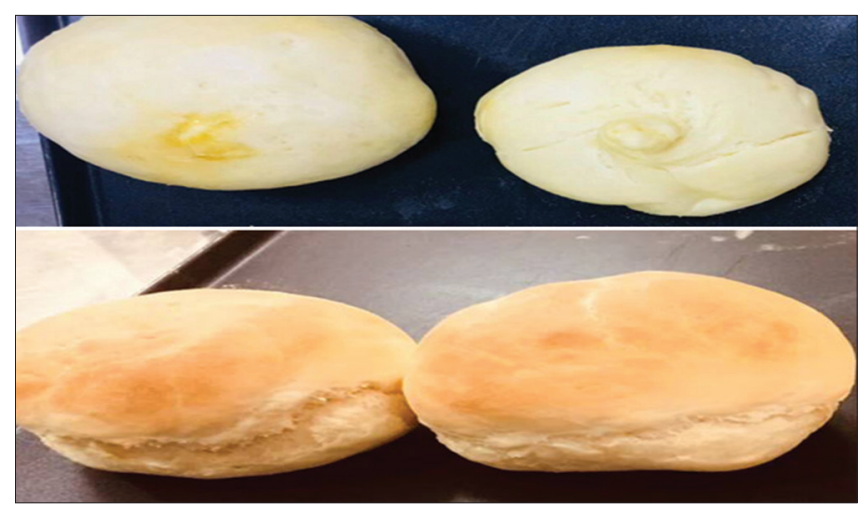

Fig 3. Samples of final products (lower - oven baked bread; upper steamed bread) baked bread samples to $2655.60 \mathrm{~g}$ after three days with subsequent increase to $3484.90 \mathrm{~g}$ after four days while for steamed bread the increase was from $1266.87 \mathrm{~g}$ after three days with further increase to $5928.20 \mathrm{~g}$ after four days (105 h). Overall, the highest resilience was observed for oven baked bread at room temperature at $72 \mathrm{~h}$ while for steam bread it was also at room temperature at $105 \mathrm{~h}$. The highest firmness was observed in both oven baked and steamed bread at room temperature after four days at $105 \mathrm{~h}$. The resilience and firmness on the first day $(0 \mathrm{~h})$ at both refrigeration and freezing temperature were not measured to allow sufficient time under these conditions. Storage time resulted in a gradual decrease on the specific volume of steamed bread, because of a decrease in the moisture of steamed bread due to a breakdown in some of the hydrogen bonds between water and gluten protein and the holding capacity of gas is impaired thereby reducing the volume (Li et al., 2018).

The supplementation with banana milk juice and its concentration in dough might be a key factor to affect the resilience and firmness of bread. In this study, we compared the resilience and firmness of bread with different processing methods, and the effect of supplementation on the dough were investigated. Afterwards, the effect of storage temperature on the resilience and firmness was further explored. When supplemented with banana milk juice at varying concentrations, the results showed that more banana milk juice in bread could lead to lower resilience but more firmness in both oven baked and steamed bread. The effect of storage at room temperature over time on the resilience and firmness of both oven baked and steamed bread are as shown in Table 2

On the first day $(0 \mathrm{~h})$, as the level of supplementation increased from $10 \%$ to $50 \%$, there was a decrease in resilience from $20.02 \mathrm{~g}$ to $18.58 \mathrm{~g}$ in oven-baked bread. A similar decrease in resilience was observed from $51.27 \mathrm{~g}$ to $48.62 \mathrm{~g}$. Resilience increased over storage time in both types of bread. The firmness increased from $455.26 \mathrm{~g}$ to $465.28 \mathrm{~g}$ for oven-baked bread while for steamed bread it increased from $413.46 \mathrm{~g}$ to $416.92 \mathrm{~g}$ on the first day $(0 \mathrm{~h})$. In both types

Table 3: Effect of storage temperature and time on the textural characteristics of oven baked and steamed bread*

\begin{tabular}{|c|c|c|c|c|c|c|c|c|c|c|}
\hline \multirow[t]{2}{*}{ Property } & \multirow[t]{2}{*}{ Bread type } & \multicolumn{3}{|c|}{ RT } & \multicolumn{3}{|c|}{$4^{\circ} \mathrm{C}$} & \multicolumn{3}{|c|}{$-20^{\circ} \mathrm{C}$} \\
\hline & & $\mathrm{Oh}$ & $72 \mathrm{~h}$ & $105 \mathrm{~h}$ & $\mathrm{Oh}$ & $72 \mathrm{~h}$ & $105 \mathrm{~h}$ & $\mathrm{Oh}$ & $72 \mathrm{~h}$ & $105 \mathrm{~h}$ \\
\hline \multicolumn{11}{|c|}{$\begin{array}{l}\text { Resilience } \\
\text { (g) }\end{array}$} \\
\hline & OBB & 20.2 & 100.0 & 99.0 & nd & 22.2 & 75.9 & nd & 61.4 & 63.9 \\
\hline & CSB & 51.5 & 60.4 & 65.1 & nd & 61.2 & 52.3 & nd & 19.5 & 55.4 \\
\hline \multicolumn{11}{|c|}{ Firmness (g) } \\
\hline & OBB & 452.5 & 3933.1 & 12824.4 & nd & 3000.0 & 4794.2 & nd & 2655.6 & 3484.9 \\
\hline & CSB & 412.0 & 2569.1 & 6502.7 & nd & 1364.7 & 5928.2 & nd & 1266.9 & 1655.0 \\
\hline
\end{tabular}

*Mean value of 20 samples; RT, room temperature; OBB, oven baked bread; CSB, Chinese steamed bread; nd, not determined 
of bread, the firmness increased over storage time. Bread firmness is affected by baking temperature and time. An increase in baking temperature and time causes an increase in bread firmness with the highest baking temperature producing the hardest bread (Keskin et al., 2004).

\section{Sensory characteristics of oven baked and steamed bread}

Food has to be consumed first before their nutritional effects can be utilized in the body. The choice of a food product are often influenced by their textural and sensory characteristics. In order to improve the sensory and nutritional characteristics of steamed and oven baked bread doughs, they were supplemented with banana milk juice at varying levels. Banana is a good source of quick energy rich in nutrients with a variety of essential vitamins and minerals such as potassium, phosphorus, iron, and active ingredients such as resistant starch, polysaccharides, polyphenols, carotenoids, and catecholamines (Pereira and Maraschin, 2015, Kyamuchangine et al., 2002). A higher dietary intake of potassium has been associated with lower rate of stroke and may also reduce the incidence of cardiovascular disease (D’Elia et al., 2011). Dopamine (a strong water-soluble antioxidant), which is one of the catecholamines was identified in commercial banana Musa cavendishii (Kanazawa and Sakakibara, 2000). A unique formula in which banana is incorporated into bread may offer nutritional and medicinal value, such as anti-ulcer, hypoglycemic, anti-tumor, anti-depression, anti-oxidation, diarrhoea, prevention and treatment of neurodegenerative diseases (Kumar et al., 2012; Jyothirmayi and Rao, 2015).

The use of sourdough as a natural starter for leavening goods is one of the oldest biotechnological processes in food fermentation (Röcken and Voysey, 1995). A comprehensive review (Chavan and Chavan, 2011) reported on how sourdough can improve the texture, flavor, nutritional value and shelf life of bread. The positive effects of sourdough were associated with the metabolic activities of sourdough-resident microorganisms, they include lactic acid fermentation, proteolysis, exopolysaccharides (EPS) production and synthesis of volatile and antimicrobial compounds (Corsetti et al., 2000, Arendt et al., 2007).

The ingredients that make up the dough, processing conditions, yeast activity, fermentation temperature, and gas bubble formation are mainly responsible for the development of a porous crumb (Sozer at al., 2011; Rathnayake et al., 2018).

The internal structure (crumb) of the bread in varying sizes are as shown in Fig. 4 It seems with $30 \%, 40 \%$ and $50 \%$ banana milk juice supplementation; there was a very noticeable lack of holes in the crumbs visually. As the level of banana milk juice increased, the firmness of the crumbs also increased in both steamed and oven-baked bread. The sensory panelists were of the opinion that $-20{ }^{\circ} \mathrm{C}$ keeps better after 4 days (105 h) with banana supplemented bread in both types.

It was suggested that a bread product with a well-developed porous crumb structure may contain the property of higher gas retention capacity which results in an increased volume and reduced crumb hardness with appealing sensorial properties (El-Sohaimy et al., 2019).

Since steamed bread utilize steam from boiling water, the relative humidity is high, which results in making the skin soft, white, and there is no hard crust as a rigid support. Its structure is tighter than oven baked bread. The baked bread is at a high temperature, so a golden hard shell is formed on the surface to support the bread. Because of high-temperature in the oven-baked process, a series of complicated physical and chemical reactions occur in bread, including the complexity of the Maillard reaction. During the bread making process, special flavor substances are produced, and the structure of the bread becomes relatively bulky (Schober et al., 2007).

In the global efforts to reduce greenhouse gas emissions and mitigate climate change, there is a need to seek plant-based alternatives to meat as a source of protein. One important way to achieve this is to develop new food products that have less impact on the environment. Bread, as a staple food in many countries can be improved nutritionally with protein ingredients from meat alternatives. For instance, an enriched protein bread was made from wheat flour, dried crickets flour and seeds by Fazer bakeries in Finland (Forsell, 2017).

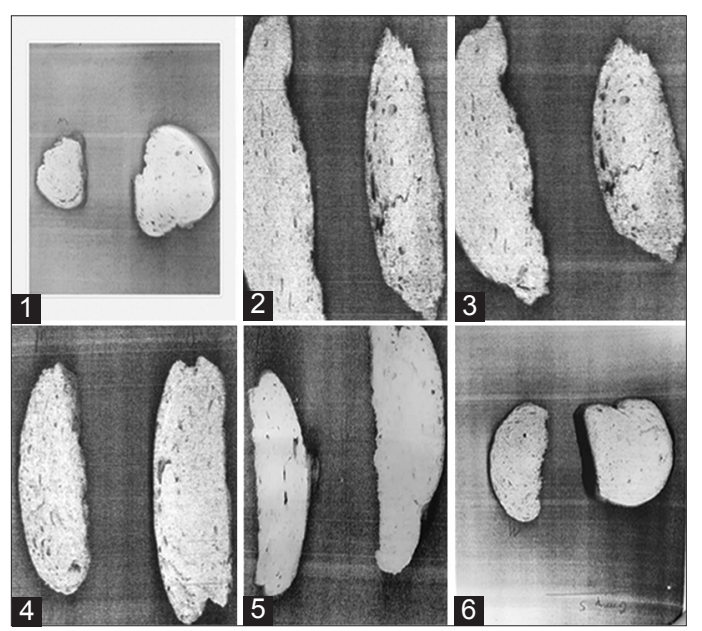

Fig 4. Internal structure (crumb) of oven baked and steamed bread 1. No banana milk juice, 2. $10 \%$ banana milk juice, 3. $20 \%$ banana milk juice, 4 . $30 \%$ banana milk juice, $5.40 \%$ banana milk juice, 6.50 $\%$ banana milk juice 
Table 4: Scores from sensory evaluation test

\begin{tabular}{|c|c|c|c|c|c|}
\hline & Shape & Surface color & Internal color & Internal organization structure & Distribution uniformity of internal structure \\
\hline \multicolumn{6}{|l|}{ Steam bread } \\
\hline & 8 & 7 & 9 & 7 & 5 \\
\hline & 6 & 6 & 7 & 6 & 5 \\
\hline & 7 & 7 & 8 & 8 & 8 \\
\hline & 7 & 8 & 6 & 8 & 7 \\
\hline & 5 & 5 & 7 & 6 & 7 \\
\hline & 7 & 8 & 9 & 7 & 8 \\
\hline & 9 & 8 & 7 & 5 & 3 \\
\hline Average score & 7 & 7.00 & 7.75 & 6.71 & 6.14 \\
\hline $\mathrm{SD}^{\mathrm{c}}$ & 1.29 & 1.15 & 1.13 & 1.11 & 1.86 \\
\hline $\mathrm{RSD}^{\mathrm{d}}$ & 0.21 & 0.16 & 0.38 & 0.17 & 0.30 \\
\hline \multicolumn{6}{|l|}{ Baked bread } \\
\hline & 6 & 7 & 8 & 6 & 6 \\
\hline & 9 & 7 & 1 & 5 & 3 \\
\hline & 6 & 7 & 7 & 6 & 7 \\
\hline & 6 & 8 & 6 & 7 & 8 \\
\hline & 7 & 5 & 5 & 8 & 7 \\
\hline & 9 & 9 & 8 & 7 & 8 \\
\hline & 7 & 8 & 8 & 7 & 6 \\
\hline Average score & 7.14 & 7.29 & 6.14 & 6.57 & 6.43 \\
\hline SD & 1.35 & 1.25 & 2.54 & 0.98 & 1.72 \\
\hline RSD & 0.19 & 0.17 & 0.41 & 0.15 & 0.27 \\
\hline
\end{tabular}

'SD: standard error; ${ }^{\mathrm{d}} \mathrm{RSD}$ : relative standard deviation.

The sensory panelists (70 students) rated both oven and steamed bread, the scoring criteria is shown in Table 3 while the average scores are shown in Table. 4

A novel formulation with food ingredients that improves the nutritional quality no data and shelf life of steamed bread, which is part of the dietary culture in China may be worthy of further research. Our work as a preliminary investigation on the texture and sensory characteristics of oven baked and steamed bread can be extended with the hope of assessing its commercial viability in the Chinese market. The best storage temperature and shelf life should be declared on the label of such new steamed bread products.

Apart from the textural and sensory characteristics with the use of sourdough, there are also indications of its use in gluten free bread, which can help to improve the quality, safety and acceptability of such bread (Moroni et al., 2009, Lynch et al., 2018). There is a global interest in the demand for high quality gluten-free bread, clean labels and natural products. This niche can be met with further studies in gluten free bread-making that employ the use of sourdough and other enriched protein sources in the nearest future.

\section{CONCLUSIONS}

In this study, the resilience and firmness of bread increased after three days when stored at room temperature, $4{ }^{\circ} \mathrm{C}$ and $-20{ }^{\circ} \mathrm{C}$ in both oven baked and steamed bread. With the addition of $50 \%$ banana milk juice to improve the nutritional quality of both oven baked and steamed bread, the resilience decreased for both types of bread on the first day. This indicates the need for further investigation to ensure that the resilience of fresh bread supplemented with banana milk juice at higher levels is not compromised with improved nutritional quality.

\section{FUNDING}

There is no funding for this research.

\section{ACKNOWLEDGEMENTS}

The authors would like to thank the "Food Ingredients" students at the College of Food Science, Sichuan Agricultural University, China for their active participation in the experiment. We also thank 'Sour dough research student' Zhenghai Zeng for his help with the samples and the sour dough starter.

\section{CONFLICT OF INTEREST}

The authors of this research declare no conflict of interest. 


\section{Authors' contributions}

DR planned the experiment, DR, AL and CL wrote the paper.

\section{REFERENCES}

Arendt, E. K., L. A. Ryan and F. D. Bello. 2007. Impact of sourdough on the texture of bread. Food Microbiol. 24(2): 165-174.

BIRT. 2010. Baking Industry Research Trust. Chinese Steamed Bread Information Sheet. from: https://www.bakeinfo.co.nz/files/ file/101/BIRT_Chinese_Steamed_Bread_Info_Sheet.pdf. [Last accessed on $2018 \mathrm{Jul} 16]$.

Chavan, R. S. and S. R. Chavan. 2011. Sourdough technology a traditional way for wholesome foods: A review. Compr. Rev. Food Sci Food Safety. 10: 169-182.

Corsetti, A., M. Gobbetti, B. De Marco, F. Balestrieri, F. Paletti and J. Rossi. 2000. Combined effect of sourdough lactic acid bacteria and additives on bread firmness and staling. J. Agric. Food Chem. 48: 3044-3051.

D'Elia, L., B. Gianvincenzo, F. P. Cappuccio and P. Strazzullo. 2011. Potassium intake, stroke, and cardiovascular disease: A meta-analysis of prospective studies. J. Am. Coll. Cardiol. 57(10): 1210-1219.

El-Sohaimy, S. A., M. G. Shehata, T. Mehany and M. A. Zeitoun. 2019. Nutritional, physicochemical, and sensorial evaluation of flat bread supplemented with quinoa flour. Int. J. Food Sci. 2019: 15.

Forsell, T. 2017. Reuters News. Available from: https://www.reuters. com/article/us-finland-ediblebugs/finland-baker-launchesbread-made-from-crushed-crickets-idUSKBN1DN17E. [Last accessed on 2019 Jan 10; Last accessed on 2018 Jul 14].

Galle, S., C. Schwab, F. D. Bello, A. Coffey, M. G. Gänzle and E. K. Arendt. 2012. Influence of in situ synthesized exopolysaccharides on the quality of gluten-free sorghum sourdough bread. Int $\mathrm{J}$ Food Microbiol. 155(3): 105-112.

He, Z. H., A. H. Liu, R. J. Pena and S. Rajaram. 2003. Suitability of Chinese wheat cultivars for production of northern style Chinese steamed bread. Euphytica, 131: 155-163.

Huang, S. D. and D.M. Miskelly. 1991. Steamed bread a popular food in China. Food Aust. 43(8): 346-347, 350-351.
Jyothirmayi, N. and N. Rao. 2015. Banana medicinal uses. J. Med Sci. Technol. 4(2): 152-160.

Kanazawa, K. and H. Sakakibara. 2000. High content of dopamine, a strong antioxidant, in Cavendish banana. J. Agric. Food Chem. 48(3): 844-848.

Keskin, S.O, G. Sumnu, and S. Sahin (2004). Bread baking in halogen lamp microwave combination oven. Food Res. Int. 37(5): 489-495.

Kumar, K. S., D. Bhowmik, S. Duraivel and M. Umadevi. 2012 Traditional and medicinal uses of banana. J Pharmacogn Phytochem, 1(3): 51-63.

Kyamuchangine, W., H. Myhre, H. T. Sorensen and R. Rehrson. 2002. Yield, characteristics and composition and banana juice extracted by the enzymatic and mechanical methods. J. Sci. Food Agric. 82: 478-482.

Li, W., S. Zhang, Y. Feng, Z. Wang and H. Han. 2018. Effects of Storage Time on Steamed Bread Quality and Gluten Protein Structure. IOP Conference Series: Materials Science and Engineering.

Lynch, K. M., A. Coffey and E. K. Arendt. 2018. Exopolysaccharide producing lactic acid bacteria: Their techno-functional role and potential application in gluten-free bread products. Food Res. Int. 110: 52-61.

Moroni, A.V., F. D. Bello and E. K. Arendt. 2009. Sourdough in glutenfree bread-making: An ancient technology to solve a novel issue? Food Microbiol. 26(7): 676-684.

Pereira, A. and M. Maraschin. 2015. Banana (Musa spp) from peel to pulp: Ethnopharmacology, source of bioactive compounds and its relevance for human health. J. Ethnopharmacol. 160: 149-163.

Qarooni, J., J. G. Ponte and S. Posner. 1992. Flat breads of the world. Cereal Foods World. 37: 863-865.

Rathnayake, H. A., S. B. Navaratne and C. M. Navaratne. 2018. Porous crumb structure of leavened baked products. Int. J. Food Sci. 2018: 15

Röcken, W. and P. A. Voysey. 1995. Sourdough fermentation in bread making. J. Appl. Microbiol. 79: 38S-48S.

Sozer N, H. Dogan and J. L. Kokini. 2011. Textural properties and their correlation to cell structure in porous food materials. J. Agric. Food. Chem. 59(5): 1498-1507.

Xiao, W. J. 2018. Study on bread quality evaluation. J. Food Safety Guide. 12: 62-63. 